\title{
Research on the Game between Private Investment and Government Investment in Shaanxi
}

\author{
Xirong Wang ${ }^{1, a^{*}}$ and Yan Gui ${ }^{2, b}$ \\ ${ }^{1}$ School of Management, Yulin University, China, 719000 \\ ${ }^{2}$ The First Middle School of Yulin, China, 719000 \\ a250661321@qq.com, b676969012@qq.com
}

Keywords: Private investment; Government investment; Shaanxi; Research on game

\begin{abstract}
In order to more effectively eliminate influence of Shaanxi folk capital investment barriers, and promote the economic development of Shaanxi. The paper established the evolutionary game model of government investment and private investment, and analyzes the dynamic game process between government investment and private investment. Then obtain the dynamic game relation and development strategy about the government and folk capital in Shaanxi investment.
\end{abstract}

\section{Introduction}

Under the background of reform and Opening-up, the socialist road which belongs to the Chinese characteristics initially completed, resulting in speeding up the de velopment speed of each industry in china. Along with our country comprehensive strength promotion, now China is moving forward to the diversification of society. In each industry investment has become the main way of China's economic pull. And when the financial crisis struck, the investment also plays an irreplaceable role in our country's regulation. The situation in the socialist primary, improve the basic economic system has become the primary task of the further development of the economy. However, folk investment is the non state owned economic subject, because of regional and historical reasons such as causing the development is not balanced, i.e., the southeast area is developed and the northwest area is relatively backward. In order to find out the main obstacle to the investment of folk capital in Northwest area, This paper will analyze in detail according to the Shaanxi folk capital investments in China, The analysis of the evolution of the relationship between government investment and folk investment, and find out the effective strategies to promote the development of Shaanxi folk capital investment.

\section{Game Analysis of Government Investment and Folk Investment}

By the analysis of the situation of Shaanxi Province, in solving the problem of Shaanxi folk capital investment, how to treat the relationship between government investment and folk investment has great influence. For Shaanxi Province, the proportion of folk investment is far better than government investment, to promote the Shaanxi folk capital investment; we need to drive and motivation of government investment to the external force. According to the following game analysis, the government and the folk capital as the object of the game, Now suppose that the government drives the folk capital invest but the folk capital does not support the investment, the government benefit for ${ }^{x_{1}}$, the folk capital benefit for 0 ; In turn the folk capital to actively invest but the government does not drive, the folk capital benefit for ${ }^{x_{1}}$, the government benefit for ${ }^{x_{2}}$. When the government and the folk capital is a positive attitude, government revenue for $x$, the folk capital for ${ }^{x}$; if it is not positive, then the benefits for both sides are 0 . Table 7 is the payoff matrix of government and the folk capital. 
Table 1 The payoff matrix of government and the folk capital

\begin{tabular}{|c|c|c|c|}
\hline & & \multicolumn{2}{|c|}{ the folk capital } \\
\hline & & invest & Don't invest \\
\hline \multirow{2}{*}{ government } & drive & $x, x^{\prime}$ & $x_{1}, 0$ \\
\hline & Don't drive & $x_{2}, x_{1}^{\prime}$ & 0,0 \\
\hline
\end{tabular}

Among them, the ${ }^{x^{\prime}, x_{1}^{\prime}}$ in size cannot be determined, and $x>x_{1}>x_{2}$, therefore to establish the evolutionary game model of government and the folk capital to analyze the actual situation to the problem of Shaanxi folk capital investment, and make their strategic adjustment.

\section{Evolutionary Game Analysis of the Relationship between Shaanxi Folk Capital Investment and Government Investment}

For the government and the folk capital are independent and random in the problem of Shaanxi folk capital investment, and can carry on the repeated game. Therefore, the probability of government drives the folk capital is the ${ }^{y}$, the probability of not driving for the ${ }^{1-y}$; the probability of the folk capital invest is $z$, the probability of not reform for the $1-z$; According to

the Malthusian theorem, the government strategy choice drives the growth rate $\left({ }^{y}\right)$ should be the number of fitness $\left(E_{w} Y\{f, 1-q\}^{T}\right)$ and average fitness $(y, 1-y\} Y\{z, 1-z\}^{T}$ ) difference. When the government droved the probability is $1, E_{w}=[1,0]$, the benefit matrix is $Y=\left[\begin{array}{cc}x & x_{1} \\ x_{2} & 0\end{array}\right]$, and $\dot{y}=y(1-y)\{1,-1\} Y\{z, 1-z\}^{T}$ Simplify to

$\dot{y}=y(1-y)\left[\left(x-x_{1}-x_{2}\right) z+x_{1}\right]$

Similarly, the folk capital strategy choice to invest the growth rate $(z)$ should be the number of fitness $\left(E_{J} Z\{z, 1-z\}^{T}\right)$ and average fitness $\left(\{z, 1-z\} Z\{y, 1-y\}^{T}\right)$ difference. When the folk capital invest of choice probability is $1, E_{w}=[1,0]$, the benefit matrix is $Z=\left[\begin{array}{ll}x^{\prime} & 0 \\ x_{1}^{\prime} & 0\end{array}\right]$, and $\dot{z}=z(1-z)\{-1,1\} Z\{z, 1-z\}^{T}$ Simplify to

$\dot{z}=z(1-z)\left[x_{1}^{\prime}+\left(x^{\prime}-x_{1}^{\prime}\right) y\right]$

So when the $\dot{y}=0, \dot{z}=0$, the balance point for the problem of Shaanxi folk capital investment are $(0,0),(0,1),(1,0)$ and $(1,1)$. According to the analysis of local stability of these equilibrium points matrix stability, ask the ${ }^{y}$ for the partial derivative of ${ }^{y}$, and the $\dot{z}$ for the partial derivative of $z$, the matrix is 


$$
R=\left[\begin{array}{cc}
\partial \dot{y} / \partial y & \partial \dot{y} / \partial z \\
\partial \dot{z} / \partial y & \partial \dot{z} / \partial z
\end{array}\right]=\left[\begin{array}{cc}
(1-2 y)\left[\left(x-x_{1}-x_{2}\right) z+x_{1}\right] & y(1-y)\left(x-x_{1}-x_{2}\right) \\
z(1-z)\left(x-x_{1}^{\prime}\right) & (1-2 z) y
\end{array}\right]
$$

Among them

$$
\begin{aligned}
\operatorname{det} R= & (1-2 y)(1-2 z)\left[\left(x-x_{1}-x_{2}\right) z+x_{1}\right]\left[x_{1}^{\prime}+\left(x^{\prime}-x_{1}^{\prime}\right) y\right] \\
& -y z(1-y)(1-z)\left(x-x_{1}-x_{2}\right)\left(x^{\prime}-x_{1}^{\prime}\right) \\
\operatorname{tr} R= & (1-2 y)\left[\left(x-x_{1}-x_{2}\right) z+x_{1}\right]+(1-2 z)\left[x_{1}^{\prime}+\left(x^{\prime}-x_{1}^{\prime}\right) y\right]
\end{aligned}
$$

Table 2 is the local stability of the equilibrium point.

Table 2 the local stability of the equilibrium point

\begin{tabular}{|c|c|c|c|c|c|}
\hline $\begin{array}{c}\text { the } \\
\text { equilibrium } \\
\text { point }(y, z)\end{array}$ & \multicolumn{2}{|c|}{$t r R$} & \multicolumn{2}{c|}{$\operatorname{det} R$} & stability \\
\hline$(0,0)$ & $x_{1}+x_{1}^{\prime}$ & + & $x_{1} \cdot x_{1}^{\prime}$ & + & $\begin{array}{c}\text { Unstable } \\
\text { point }\end{array}$ \\
\hline$(0,1)$ & $x-x_{2}-x_{1}^{\prime}$ & - & $-\left(x-x_{2}\right) \cdot x_{1}^{\prime}$ & Unknown & $\begin{array}{c}\text { Saddle } \\
\text { point }\end{array}$ \\
\hline$(1,0)$ & $x^{\prime}-x_{1}$ & - & $-x_{1} \cdot x^{\prime}$ & Unknown & $\begin{array}{c}\text { Saddle } \\
\text { point }\end{array}$ \\
\hline$(1,1)$ & $-\left(x-x_{2}+x^{\prime}\right)$ & + & $\left(x-x_{2}\right) \cdot x^{\prime}$ & - & Stable point \\
\hline
\end{tabular}

From the table shows, point $(0,0)$ is the unstable point, and $(0,1),(1,0)$ are the saddle points, the evolutionary stable point is $(1,1)$. Figure 3 is the strategy evolution diagram.

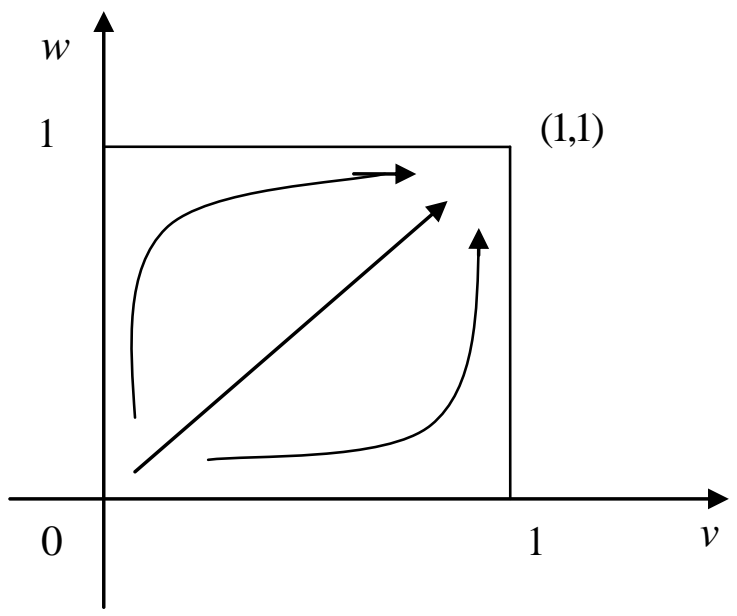

Figure 1. The strategy evolution diagram

From the figure shows, we can find the best strategy about the government and the related education department handling of the Shaanxi folk capital investment problems. Folk capital should be more actively involved in investment, accelerating the construction of Shaanxi folk capital 
investment; the government should also increase investment, stimulate and promote folk capital flows, to drive the Shaanxi folk capital investment positive development.

\section{Conclusion}

This paper established the evolutionary game analysis model; find the best strategy about the government and the related education department handling of the Shaanxi folk capital investment problems. Folk capital should be more actively involved in investment, accelerating the construction of Shaanxi folk capital investment; the government should also increase investment, stimulate and promote folk capital flows, to drive the Shaanxi folk capital investment positive development.

\section{References}

[1] Wang Yuling. Explore the problem of how to expand private investment in financial crisis, [J]. Chinese collective economy, 2009 (16)

[2] Zhang Hanya. The advice about guide non-governmental investment [J].China investment, $2014(5)$

[3] Tang Min. A pressing matter of the moment to ensure growth is to stimulate private investment [J]. China foreign, 2009, (03)

[4] Chao Xiaojing, Ren Baoping. Economic transition, private investment and government investment to growth -- Empirical analysis of Chinese investment driven growth of economic high speed [J]. Economic science, 2008, (02)

[5] Huang Minyou. The synergistic action of government investment and private investment in recovering economy [D]. Guangxi Normal University, 2014

[6] Han Zhifeng. Study on the regulation of investment Chinese government [A]. Graduate School of China Academy of Social Sciences, 2014

[7] Li Yihua. Chinese local government investment research [D]. Xiamen University, 2012

[8] Ma Xiaojun, NieJing. Effect of China government investment on private investment -- Taking Beijing and Shanghai as an example [J].Heilongjiang foreign trade and economy, 2009 (9)

[9] TangMin. How to stimulate private investment [J]. Contemporary managers, 2013 (1)

[10] Hu Ping, Zhang Xiaoting. Four trillion investments to private investment crowding out effect analysis [J]. Trade in the north, 2010 (1)

[11]Zhong Dajun. The conversion of the macro-control and future economic trends in Chinese [J]. Chinese ocean shipping, 2010 (1)

[12]Liu Gang. The difficult and key about activation of private investment [J]. China development observation, 2009 (12) 